\title{
LOS TRIBUNALES DE LOS ALCADÍES MOROS EN LAS ALJAMAS MUDÉJARES VALENCIANAS
}

\author{
MANUEL V. FEBRER ROMAGUERA
}

\section{SUMARIO}

I. El tribunal o «cort de l'alcadí». - I.1. Introducción. - I.2. El alcadí, presidente del tribunal. - I.3. Alcadíes auxiliares, sustitutos, asesores. - I.4. Los alfaquíes. - I.5. Procuradores de pleitos. - II. Los auxiliares de la «cort de l'alcadi". - II.1. Los «escribans». - II.2. Los "torcimanys". - II.3. El "çalmedina». - II.4. Los «xurtins». - II.5. Otros auxiliares judiciales: «carceller», «botxí» o «morro de vaques». - Documentos.

\section{EL TRIBUNAL O «CORT DE L'ALCADÍ»}

\section{I.1. Intraducción}

El deber de consulta impuesto doctrinalmente a los cadíes del Occidente musulmán, especialmente de $\mathrm{Al}$-Andalus, se remontaba a las prácticas judiciales inmediatamente posteriores a la conquista islámica de estos territorios. El uso inicial pasó a convertirse con el tiempo en costumbre normativa, según la doctrina, creándose a nivel general los «consejos de juristas», cuya competencia fue eminentemente consultiva para asesoramiento de los cadíes, sobre los cuales recaía personalmente la obligación de impartir justicia, según el principio imperante de *unicidad de jurisdicción" '.

' Emile TYAN, Kädt, en «Encyclopédie de l'Islam» (2.' Edition), IV, p. 390. La obra básica sobre la organización judicial de los paises islámicos en la Edad Media es la de Émile TYAN, Histoire de l'organisation judiciaire en pays d' Islam, Leyden, 1960. También de Évariste 
Las jurisdicciones especiales (mazalìm, hisba y šurta) del periodo de dominación islámica, no afectaban al principio de unicidad jurisdiccional cadial, por cuanto sus detentadores eran como el cadí delegados del detentador del poder político (califa).

Estos caracteres se mantuvieron en el periodo mudéjar esencialmente en las causas de exclusiva intervención de los alcadíes, pues en las causas en las que los alcadíes eran jueces asesores del baile general de Valencia, de uno local, o de cualquier señor o procurador señorial, el principio no se aplicaba claramente, por existir una jurisdicción compartida, aunque si que encontramos la existencia de un tribunal con presidencia de un juez cristiano y unos consejeros-juristas moros.

Otro asunto era el del nombramiento de sustitutos o lugartenientes de alcadí por el propio rey, o el baile general del reino, o incluso por los propios alcadíes generales, a fin de que actuaran en periodos en que el alcadí titular estuviera ausente de un lugar o demarcación. Por otra parte, estos sustitutos, en calidad de juristas, podían intervenir como asesores en los consejos que los alcadíes convocaran cuando lo creyeran necesario ${ }^{2}$.

Como el propio nombre de consejero indica, su propia función era la de aconsejar al alcadí titular del tribunal en las causas que por su delicadeza se les requería para ello. Según algún alfaquí malikí, el alcadí no podía tener válidamente audiencia si no contaba con la asistencia de un consejo de personas entendidas en la ley islámica; es decir, que tuvieran la condición de alfaquíes. Estos consejeros-alfaquíes deberían reunir las condiciones de: moralidad y de piedad religiosa requeridas para que el alcadí pudiera confiar en su consejo libre.

Su nombramiento era "ad hoc», sin que diera lugar a ningún tipo de cargo oficial. Sólo eran personas entendidas que eran consultades extraordinariamente, cuando el caso lo requería, sin que ello supusiera una práctica obligatoria y continuada de la actividad en el tribunal '.

De este modo, del tribunal o «Cort de l'Alcadí» de las morerías valencia-

LÉvi-Provençal, Historia de España Musulmana, en «Historia de España dirigida por R. Menéndez Pidal", V (II), Madrid, 1956. Igualmente, de Joseph SCHACHT, An introduction to Islamic Law, Oxford, 1979, pp. 23-24. Y de José J. LÓPEZ ORTIZ, Derecho musulmán, Barcelona, 1932, pp. 71 y ss. Más conciso es Maurice GAUDEFROY-DEMOMBYNES, Institutions musulmanes, Paris, 1946.

${ }^{2}$ Emile TYAN, Histoire de l'organisation judiciaire, ob. cit., pp. 214-219. También: Archivo de la Corona de Aragón (ACA), Cancillería Real (CR), Registro (reg.) 862, fol. 119v. a 120r. Como complemento puede consultarse la obra de R. I. BURNS, L'Islam sota els croats, València, 1990, I, pp. 333-391.

Ibidem, pp. 214-219. 
nas, formaban parte, no sólo su presidente o alcadí, sino también una serie de personajes: «llochtinents d'alcadí», «alfaquís», «procuradors de pleyts», «escribáns», "çalmedina» o "xurtí», "turcimanys», "carceller» y «botxins» o «morros de vaques».

La naturaleza de cada uno de estos personajes era distinta, pues, frente al carácter de simples auxiliares de la justicia de unos (turcimany, botxí, carceller o xurtí), otros podrían calificarse de colaboradores de la justicia (procurador de pleyts), siendo otros más bien jueces auxiliares o asesores (llochtinents d'alcadí, alfaquíns). Por ésto vamos a estudiar cada uno de los mismos por separado, tratando de detallar sus características más esenciales en lo referente a su intervención en el tribunal del alcadí moro valenciano ${ }^{4}$.

\section{I.2. El alcadi, presidente del tribunal}

Las cartas de capitulación que se fueron otorgando por Jaime I a las aljamas valencianas conforme iban pactando su rendición a medida que la conquista cristiana del reino avanzaba, solían contener la confirmación del derecho a mantener el régimen jurisdiccional islámico propio de la época de dominación musulmana. Por ello, se conservaron la mayoría de alcadiazgos del periodo anterior. Tal es el caso de las aljamas rendidas en 1238 que se citaban por el propio monarca en su crónica o «Libre dels Feyts»; entre las cuales, cabe destacar las de Almenara, Castro (Alfondeguilla), Valld'Uixó, Nules, Paterna, Bétera, Bufilla y otras'.

Lo mismo se había visto tempranamente en los pactos de capitulación otorgados respectivamente por la Orden del Hospital y la del Temple a las aljamas de Cervera (1233) y Xivert (1334) ${ }^{\circ}$. En el mismo sentido se pronun-

${ }^{1}$ Remitimos para otros aspecto del tema a nuestros estudios: Manuel Vte. FEBRER ROMAGUERA, La organización judicial de las aljamas mudéjares valencianas y la Sunna y Xara, en «XIII Congreso de Cronistas Oficiales de España-XVI Asamblea de Cronistas Oficiales del Reinon, XVI (1986), pp. 193-217. ID., Los Bellvis: una disnatia mudéjar de alcadies generales de Valencia, Aragón y Principado de Cataluña, en "III Simposio Internacional de Mudejarismon, (Actas), III (1986), pp. 277-290.

ID., Justicia mudéjar en la Valencia foral, en "Estudios en homenaje al Profesor J.J.López Ortiz», Madrid, 1993.

' Libre dels Feyts, Edición de Ferran Soldevilu, Barcelona, 1971. Caps. 243, 249. 252.

- La carta de capitulación de Cervera (1233) ha sido publicada recientemente varias veces, debiéndose su hallazgo al señor Joan FERRERES NOS, Estudi de les capitulacions dels 
ciaría en 1242 el rey Jaime I en el pacto de capitulación de la aljama de la Serra d'Eslida ?.

La situación de los moros habitantes en numerosas alquerías dependientes de la ciudad de Valencia, fue bien distinta, pues, al repartirse estas comunidades a señores cristianos, la situación institucional de la justicia islámica debió sufrir un trauma considerable, al desaparecer las aljamas y consiguientemente los alcadiazgos locales, aunque el cargo de alcadí de la morería de Valencia se conservó, reconociéndosele en privilegio de 1268 la competencia sobre todas las causas referentes a moros de los términos generales de la ciudad.

El privilegio general que suponemos debió otorgar Jaime I a todos los moros para que fueran juzgados conforme a sus leyes islámicas de "Çuna e Xara», llevaba implícito el derecho a impartir la justicia los alcadíes moros existentes en las diversas morerías, según se reconoció en la mayoría de cartas de capitulación y de población que se fueron otorgando sucesivamente en los siglos XIII y XIV.

La distribución territorial de los alcadiazgos locales durante el periodo comprendido entre 1233 (carta de capitulación de Cervera) y 1330 (creación de alcadiazgos en todos los señoríos con mero imperio), se caracterizó fundamentalmente por la conservación más o menos fiel de los antiguos alcadiazgos de las «madinas» y «hisn» del periodo musulmán.

Así, encontramos que, aparecían alcadíes en Xivert, Vall d'Uixó, Xàtiva, Buñol, Valencia, Castro, Cocentaina, Perpunxent, Denia y Serra d'Eslida. En unos casos se trataba de viejas «madinas» (Xàtiva, Valencia, Denia); y, en otros, de cabezas de los distritos castrales islámicos (Xivert, Vall d'Uixó, Serra d'Eslida, Buñol, Cocentaina, Castro y Perpunxent) ${ }^{8}$.

Está claro en las cartas pueblas de Tales (1260), Castillo de Bes (Yátova y sus alquerías, 1266) y Artesa (1302), que no era necesario que existiesen alcadíes en sus respectivas poblaciones, dado que éstas se hallaban incluidas dentro de los términos de antiguos castillos, que contaban con sus alcadíes. Así,

moros de Cervera, en «Boletín del Centro de Estudios del Maestrazgo», 22 (abril-junio, 1988), pp. 41-48. Publicó la primera transcripción del texto Vicent GARCí EDO, Actitud de Jaime I en relación con los musulmanes del reino de Valencia durante los afios de la conquista (Notas para su estudio), en "Ibn Al-Abbar, polític i escriptor árab valencià: 1199-1260-Actes del Congrés Internacional Ibn Al-Abbar i el seu tempsw, Valencia, 1990, pp. 313-316.

Respecto a la transcripción de la capitulación de Xivert (1234), puede consultarse nuestra colección documental: Manuel Vte. Febrer Romaguera, Cartas pueblas de las morerias valencianas y documentación complementaria, I, Zaragoza, 1991, doc. 1.

' Manuel Vte. Febrer RomaguerA, ob. cit. supra, doc. 3.

- YAQUT, La España musulmana en la obra de Yaqut, Traducción de Gamal 'ABD-alKarim, en «Cuadernos de Historia del Islam», 4 (1974), pp. 281, núm. 344. 
Tales y Artesa, pertenecían al alcadiazgo de Onda, mientras que las alquerías del Castillo de Bes, al de Buñol, tal como la de Macastre. Por ello, los habitantes de estas alquerías, debían plantear sus cuestiones judiciales ante los alcadíes de sus distritos castrales, tal como ocurría durante la época de dominación musulmana.

De manera semejante ocurría en 1272 en la carta de población otorgada por Jaime I a la alquería de Aielo de Malferit, que por estar incluida dentro del distrito castral de Montesa, se establecía que estaría sometida a la costumbre de la referida población?.

Se conocen, no obstante, algunos casos excepcionales, claro está, pues poblaciones como Quart de Poblet, situado en los términos generales de Valencia, a pesar de que en origen debió depender judicialmente del alcadí de la ciudad, en 1279, un privilegio del rey Pedro III el Grande, reconoció a su aljama el derecho a disponer de alcadí distinto del de la morería valenciana y autónomo de ésta ${ }^{10}$. Algo semejante se preceptuó en 1298, reconociéndose al arraez de Crevillent el derecho a nombrar un alcadí en su señorío de Beniopa, junto a Gandía, a pesar de que, seguramente, en el pasado la alquería había dependido del alcadí del distrito castral de Bairén, demarcación a la que pertenecía el lugar ".

Refuerza la tesis de la persistencia relativa de los alcadiazgos del periodo de dominación islámica, el hecho antes mencionado, de que todavía en 1320 el baile general de Valencia, nombrase alcadí de Sagunt (Morvedre) al moro Azmet Elbono, siendo así que hubiera sido comprensible la inclusión de este alcadiazgo en el de Valencia, al ser ambas poblaciones de realengo y, tan próximas, que, a la larga, llegaron a disponer del mismo alcadí. Lo cierto es que, la condición de antiguo «madina» o "hisn» que había tenido Morvedre en el periodo islámico, suponía suficiente justificación para el mantenimiento del alcadiazgo local, a pesar de que la circunstancia de la comunidad islámica local no tuviera la misma importancia que en el pasado ${ }^{12}$.

Cuando en 1273, Jaime I concedió al moro Mahomat Abenhalayr el cargo de alcadí de Cocentaina, tenía que añadir que sería también alcadí de los distritos de Planes, Vall d'Alcalà, Gallinera, Penàguila, Guadalest, Confrides, Polop y Tárbena; todos los cuales habían sido antiguas demarcaciones castrales

9 ACA, CR, reg., 37, fol. 52 v.

1" lbid., reg. 44 , fol. 149 v. -150 r.

"lbid., reg. 110 , fol. $89 \mathrm{v}$.

12 Archivo del Reino de Valencia (ARV). Sección de Cancillería Real (Real). Libro número (núm.), 630, fol. 200 r. La bailía general disponía desde 1298 de la jurisdicción para enjuiciar a los moros de realengo. 
de la época musulmana, que debían haber contado seguramente con sus respectivos alcadiazgos locales ${ }^{13}$.

Pero toda esta planta o demarcación judicial quedaría progresivamente difuminada por sucesivas escisiones, agregaciones y nuevas delimitaciones de los alcadiazgos locales, que borraron los vestigios heredados del periodo islámico, configurando una dispersión territorial de los mismos conforme a nuevos criterios.

Como consecuencia del proceso de señorialización, se introdujo progresivamente una dificultad para que los antiguos alcadíes del distrito, si habían podido perdurar tras de la conquista cristiana, siguieran ejerciendo su jurisdicción sobre los territorios incluidos dentro de su vieja demarcación; ya que la mayoría de estos territorios se repartieron entre diversos señores, que ejercían diversos grados de atribuciones jurisdiccionales, según los privilegios obtenidos de la Corona, no disponiendo generalmente en sus señoríos de alcadí propio para enjuiciar a sus vasallos. Ello les obligaba a acudir a los alcadíes reales; sobre todo, mientras el mero imperio y alta jurisdicción permanecía en manos del rey, lo que suponía que tanto en casos de su jurisdicción foral primitiva (baja), como en los de la alta jurisdicción, sus vasallos no podían, teóricamente, ser enjuiciados por sus señores.

Para obviar todos estos inconvenientes, con ocasión del paso de la mayoría de señores de origen aragonés a fuero de Valencia, con el pacto contraido en las Cortes de Valencia de 1329, el rey Alfonso IV el Benigno, otorgó además de la llamada "Jurisdicción Alfonsina» a los señores de lugares poblados por más de tres casas de moros, el privilegio de que todo señor poseedor del mero imperio, pudiera nombrar alcadíes moros para sus propios territorios, con el consejo de los cuales las cortes señoriales deberían determinar los litigios que se ventilasen entre moros. Los señores que sólo poseyeran la «Jurisdicción Alfonsina»; es decir, parte de la jurisdicción criminal con el mixto imperio, deberían determinar los juicios que surgiesen en los territorios de su señorío y se refiriesen a moros, aconsejados de un alcadí real, o del señorío que detentase el mero imperio en su demarcación, no pudiendo imponer penas de muerte, mutilación de miembro o de más de cien azotes, pues ese tipo de procesos pertenecían sólo a los detentadores del mero imperio.

Los señores que tuvieran enclavado su señorío dentro de la jurisdicción alta y mero imperio de otro señorío, sólo podrían ejercer la Jurisdicción Alfonsina dentro de sus señoríos propios, caso de tenerlo poblado por más de seis casas de moros ${ }^{14}$.

"ACA, CR, reg. 19, fol. 18 r.

14 Furse Ordinacions fetes per los gloriosos reys d'Aragó als regnicols del Regne de València, (Edición de Lambert Palmart reeditada en facsímil en 1977). Cortes de 1329, pp. 206. 
Con los privilegios dados por Alfonso IV (II de Valencia), en enero de 1330, fueron surgiendo así alcadiazgos en la mayoría de los señoríos que poseían el mero imperio, a pesar de que en los mismos, antes de los referidos privilegios, no hubiera existido ningún alcadí moro.

Aparte, no quedaron las poblaciones de realengo al margen de la nueva normativa sobre nombramiento de alcadíes, pues el mismo monarca simultáneamente reguló que el baile general de Valencia nombrara en las tierras de mero imperio real el suficiente número de alcadíes para que atendieran las causas referentes a la impartición de la justicia islámica "s.

Siguiendo la referida normativa, conocemos que el baile general nombraría en los años siguientes numerosos alcadíes en morerías de realengo, como el de Vall de Guadalest, Jahie Atnaiar, nombrado en 1337 por el lugarteniente del baile general Jaume Castellet ${ }^{16}$. El año precedente, el propio baile general de Valencia, el célebre Arnau Çamorera, nombraba alcadí general del Rey a Mahomat Altaraçoni, y alcadí Ultra Xùquer al moro de Castelló de Rugat, Abdolaziz Abenamancor, conociéndose también otros nombramientos ".

En las tierras de señorío vemos ejemplos de nombramientos de alcadíes particulares, como el de «Mahomat Abenaex, como «alcadi general de tota la mi terra", nombrado por don Pedro de Jérica, para toda la "Tenencia de Jérica», antes de 1346, en que lo vemos ejercer su cargo ${ }^{18}$. A pesar de estos nombramientos de alcadíes territoriales, vemos que habían perdurado los alcadiazgos locales antiguos reconocidos en privilegios reales o pactos de capitulación. Tal es el caso del alcadí de Eslida, Abdumelich Abolaix, que en 1337, pese a hallarse enclavada la población dentro del territorio de la referida Tenencia de Jérica, seguía ejerciendo su cargo de alcadí independientemente del general de la tenencia nombrado por don Pedro de Jérica ${ }^{19}$.

La situación existente en los señoríos incluidos dentro de otros señoríos poseedores del mero imperio, debía ser semejante a la descrita en un privilegio otorgado en 1356 por el infante Pedro, conde de Ribagorza y de Prades, en calidad de señor de Gandía poseedor del mero imperio y alta jurisdicción en el territorio del castillo de Bairén y villa de Gandía. Este señor, disponía de un

1" Aureum opus regalium privilegiorum civitatis et regnis Valentiae (Edición de Lluís Alanyà reeditada en facsímil en 1972). Alfonsi Secundi. Priv. IX. En dicho privilegio, Alfonso IV establecía: "concedimus quod in dicto regno Valentie, tam in villis nostris regalibus ad cognitionem baiuli nostri generalis, quam in ceteris locis dicti regni ad cognitionem illorum qui in eis habent merum imperium, plures statuantur alcaldi, cum quorum consilio domini predictarum alcarearum atque locorum possint procedere..."

16 ARV, Real, núm. 630, fol. 205 r.-v.

1 Ibid., núm. 630, fol. 202 v., 203 r., 205 v.

18 Ibid., núm. 611 , fol. 218 v.

19 ACA, CR, reg. 860, fol. 185 r.-v. 
alcadí general en Gandía, al que debía recurrir Ramón del Castellá, señor de Beniarjó, Pardines y Verninça, para procesar a sus vasallos moros, por hallarse su señorío situado dentro de las tierras de alta jurisdicción del referido infante. En consecuencia, debía aconsejar sus procesos el alcadí de Gandía, no pudiendo sobrepasar sus condenas las penas de «detrimentationis membrorum aut pena flagelorum vel açotorum». El infante Pedro, se reservaba las causas en que el reo moro mereciese la pena de muerte. Del mismo modo, si el vasallo de Ramón del Castellá delinquía fuera del término del señorío de que era oriundo, en todo caso el conocimiento de la causa pertenecería a la jurisdicción del infante y a su alcadí moro de Gandía ${ }^{20}$.

A pesar de esta normativa, claramente señorializante del ejercicio de las competencias de los alcadíes moros, en no pocos lugares se confirmaría, e incluso se otorgarían nuevos privilegios, concediendo a las aljamas el derecho a nombrar sus propios alcadíes. Así, en la nueva carta puebla de la morería de Chelva y sus barrios, pese a estar en 1370 incluida en la Tenencia de Jérica, se reconoció a su aljama el derecho a disponer de su propio alcadí. Semejante privilegio se concedió en 1365 por el rey Pedro IV a la aljama de Xàtiva, confirmando un antiguo derecho de la misma vulnerado en los últimos tiempos al realizar el monarca el nombramiento de alcadíes, como Faraig de Bellvís, al margen de la aljama ${ }^{21}$.

Entre 1372 y 1430 , en poblaciones como Segorbe, Benaguasil, Vall d'Uixó y Serra d'Eslida, encontramos simultáneamente ejerciendo el cargo de alcadí a moros diversos, pese a hallarse todos estos sitios enclavados en el patrimonio del infante Martín y de su esposa la condesa María de Luna, luego reyes. Además, cuando en 1430 Alfonso V el Magnánimo (III de Valencia), confiscó en favor de la Corona Real el patrimonio del conde de Luna, don Federico de Aragón, nieto natural de don Martín y doña María de Luna, vemos que existían como alcadíes, en Benaguasil un Mahomat Abenamir, en Segorbe un Çaat Marran, y en Vall d'Uixó un Abdolaziz Duraydach, cuya situación de dependencia respecto del alcadí general del reino Ali de Bellvís (I) parece clara e incuestionable, si tenemos en consideración el hecho de que la Corona conservaba el mero imperio sobre las tierras del referido patrimonio confiscado ${ }^{22}$.

20 ARV, Real, núm. 394, fol. 28 v., 29 r.

21 Ibid., Real Justicia. Libro 8, fol. 222 v. a 226 v. (Publ. por M. Vte. Febrer Romaguera, Cartas pueblas de las morerias, ob. cit. supra, doc. 214). El dato de Xátiva está en ACA, CR, reg. 1206, fol. 138 r.-v. (Publ. parcial por John BOSWELL, The Royal Treasure. Muslim Communities under the Crown of Aragon, Yale, 1977, pp. 498-499. Completo en M. Vte. Febrer Romaguera, ob. cit. supra, doc. 207).

${ }^{22}$ En este sentido, Alfonso V el Magnánimo ya advirtió en 1418 la preeminencia del alcadí general Ali de Bellvís (I) sobre las demás magistraturas mudéjares del reino (ARV, 
La complejidad de la distribución territorial de los alcadiazgos locales en el siglo XV hace imposible tratar de clarificar la distribución geográfica de los mismos. Las intromisiones contínuas en las competencias de los alcadíes, de diversos oficiales moros de las aljamas, como alamines y alfaquíes, así como de alcaides cristianos de los castillos, procuradores señoriales y bailes locales, dificultan la delimitación de sus competencias jurisdiccionales, haciendo que resulten más formales que reales las atribuciones que doctrinalmente se les asignaban ${ }^{23}$.

En 1355 ya ordenaba el rey Pedro IV (II de Valencia), al procurador general, que removiese de sus cargos a los alcadíes que usurpaban la jurisdicción criminal que pertenecía en el reino valenciano al alcadí general Faraig de Bellvís. Antes aún, en 1298, el rey Jaime II también había ordenado que el procurador y baile general del reino evitasen que el justicia y demás oficiales cristianos de Gandía se inmiscuyesen en las competencias que tenía el alcadí moro de Beniopa. Y en 1453, encontramos que el caballero mosén Johan Vives de Canyamás, señor de Benifairó de les Valls (Vall de Segó), juzgaba a ciertos moros aconsejado por cierto alcadí llamado Ali Alaça, de Quart de les Valls, sin tener en cuenta que por tener el rey el mero imperio en Benifairó, correspondía determinar el proceso criminal al alcadí general Mahomat de Bellvís (I). El abuso señorial motivó una amonestación del baile general de Valencia Berenguer Mercader, conminándole para que revocase sus actuaciones ${ }^{24}$.

Estas irregularidades, y otras muchas, debieron ser bastante frecuentes desde fechas antiguas, debiendo estar motivadas por el hecho de que al acaparar el alcadí general del reino toda la competencia para conocer las causas referentes a moros sometidos al mero imperio real, la lejanía de unos lugares a otros impedía que el alcadí real pudiese desplazarse a determinar todos los litigios de carácter criminal. Por ello, ya en el siglo XIV se había autorizado a los Bellvís para que pudiesen nombrar lugartenientes de alcadí para la determinación de los procesos en zonas que ellos no estuviesen presentes. Este es el caso del

Real, núm. 630, fol. 207 r.-v.). Sin embargo, la situación dentro de las tierras del condado de Luna debía ser compleja, pues en ocasiones se denomina al alcadí de Benaguasil, Mahamat Abenamir, alcadí mayor de dicho patrimonio, que en tiempo de los reyes Martín y María de Luna, poseía el mero imperio y alta jurisdicción; y sin embargo, vemos actuar repetidamente por estos años al alcaldí general Ali de Bellvís (ARV, Real, núm. 625, fol. 19 r.).

24 Sobre las intromisiones de los alamines en asuntos jurisdiccionales se puede ver: Manuel Vte. Febrer ROMAGUERA, La administración económica de las aljamas mudéjares valencianas a través del estudio del oficio de alamin, en "IV Simposio Internacional de Mudejarismo", IV (Teruel), 1987. Las competencias de los alcadíes pueden verse en las obras citadas en la nota 1.

${ }^{21}$ ARV, Batlia. Letres i Privilegis, núm. 1151, fol. 737 v. 
nombramiento realizado en 1362 por Faraig de Bellvís en la persona de Çaat Alcaffaç, en la morería de Valencia ${ }^{25}$. Aparte de los nombramientos que realizaba el baile general de Valencia en lugares de realengo, según privilegio real dado en 1330, la propia Corona realizaba frecuentes nombramientos de alcadíes en poblaciones de realengo, remunerando toda clase de servicios prestados por moros. Tal es el caso del albeitar o «menescal» de Pedro IV, que fue Faraig de Bellvís, el cual alcanzó los más altos cargos dentro de la judicatura islámica. Otro ejemplo lo constituye el nombramiento en 1365 de Mahomat Abenjucef, oriundo de Eslida, que fue nombrado alcalí real en la zona "Ultra Morvedre», seguramente en agradecimiento a sus gestiones durante la capitulación de la Serra d'Eslida al final de la pasada sublevación de la misma como consecuencia de la Guerra de los Dos Pedros. También fue de nombramiento real el de Çaat Alcaffaç, como alcadí en la zona "Ultra Xixona» (1368) ${ }^{26}$.

Los nombramientos de alcadíes reales en la zona Ultra Xixona, Ultra Morvedre, e incluso en la demarcación de la Gobernación de Valencia, nada tenían que ver con las antiguas demarcaciones de los alcadiazgos del periodo musulmán, configurándose ahora en base a la delimitación de las gobernaciones y lugartenencias de gobernaciones,

- los territorios de señoríos poseedores de mero imperio, y

- las aljamas poseedoras de privilegio real para disponer de alcadí.

Los alcadiazgos señoriales se caracterizarían por la discontinuidad territorial, extendíendose a veces a varios señoríos. Con frecuencia, los señoríos cuyos señores poseían el mero imperio y no querían nombrar alcadíes, podían, o bien llamar a alcadíes de otros señoríos, tal como ocurría en 1473 en Cárcer, donde el señor, mosén Johan Martínez d'Ezllava, procedía criminalmente contra unos vasallos suyos aconsejado por el llamado en el documento «honorable Yucef Alançari, moro alcadi del loch de Carlet»" ". También podía solicitar el señor poseedor del mero imperio la concurrencia del alcadí general del reino o de otro alcadí real, que determinase la causa contra algún vasallo moro delincuente, tal como vemos que ocurría en 1460 en Vall d'Alfandec, donde el alcadí de Xàtiva, Yucef Alcamba, era requerido para ir al valle para juzgar a un moro asesino, a instancia del abad de Valldigna, señor de este valle ${ }^{28}$.

De manera general, los señores locales que no poseían el mero imperio no podían disponer de alcadíes moros, y debían notificar al baile general de Valencia o de Orihuela, según la gobernación en que se hallara el señorío, las

29 ARV, Protocolos de Ramón Bernat, núm. 2789, fol. 276 v, 277r.-v.

${ }^{26}$ ACA, CR, reg. 1209, fol. 64 r.-v. y 157 v.

27 Archivo de Protocolos del Real Colegio de Corpus Christi (Valencia). [Protocolos de Luis Saranyana, Signatura Antig. núm. 1925. Año 1473, fol. s/núm.]

28 ARV., Batlia. Letres i Privilegis, núm. 1153, fol. 10 r.-v. 
causas criminales que requerían la concurrencia del alcadí general, a fin de que el baile general de la zona enviara al referido alcadí o a lugarteniente suyo para determinar el proceso. Así ocurría por ejemplo, en 1445, en Ayódar (Castellón), donde su señor, don Johan Rois de Castellblanch, escribía una curiosa carta en aragonés, no al baile general de Valencia, sino al alcadí general Ali de Bellvís, en la que además de relatarle los hechos, le pedía que fuese a su señorío, para juzgar a unos moros de Ayódar y de la Torre Somera, que habían acuchillado a un vasallo suyo en complicidad con el alamín, ya hacía dos meses. Enterado del suceso Berenguer Mercader, baile general de Valencia, contestaba al referido señor de Ayódar:

stich maravellat de vos que, tant haja que tenits preses los dits moros, e pero lo interés del dit senyor Rey, e no m'en haveu avisat en res ${ }^{20}$.

A pesar de que el baile se excusaba de que en breve no podía ir a determinar el proceso el alcadí general, le reprochaba la tardanza en haberle notificado los hechos, que eran de su competencia por tratarse de un señorío de mero imperio real. Pensamos que, debía ocurrir de manera semejante en los demás señoríos del reino, como bien demostraba en 1401 y 1403 la reina doña María de Luna, al publicar sendas provisiones reordenando el ejercicio de las atribuciones jurisdiccionales de sus oficiales en las poblaciones de su patrimonio ". En el mismo sentido publicó en 1418 una provisión el rey Alfonso $V$ el Magnánimo, en la que decía:

... segons havem entés, en aqueix regne ha alguns alcadis, alfaquins, e alamins qui stants en nostres ciutats, viles e jurediccions reyals e no sabents nostres drets e regalies, se entrameten de fer juhis de Çuna e de Xara en les baronies, ciutats, viles e lochs de cavallers e d'altres, sens que no han liçençia de vos ne de Ali de Bellvis, nostre alcadi general en lo dit regne...

La clara intención del monarca era evitar que tales cargos de señorío se inmiscuyesen en la jurisdicción correspondiente a la bailía y al alcadiazgo general sobre los moros del realengo y alta jurisdicción y mero imperio real".

La bailía general de Valencia, regida durante el siglo XV por sucesivos representantes de la familia Mercader (1412-1490), se ocupó celosamente por preservar las competencias de los alcadíes generales sobre los litigios referentes a moros de jurisdicción real, siendo la intervención de estos oficiales de la familia

2" Ibid., núm. 1149, carta suelta junto fol. 445 v., $446 \mathrm{r}$.

10 Ibid., Real, núm. 611, fol. 150 v., 201 r.-202 r., y 213 r.

"Ibid., Real, núm. 630, fol. 207 r.-v. 
Bellvís (Ali de Bellvís (I), Mahomat de Bellvís (I) y Ali de Bellvís (II)) la que ocupa todo el periodo, sucesivamente ${ }^{32}$.

El procedimiento de enjuiciamiento era harto sencillo y sumario, según relataba a fines del siglo XIV fray Francesc Eiximenis en su obra «Regiment de la cosa pública», escrita y dedicada a los Jurados de la ciudad de Valencia. Decía así:

Los sarraïns tenen altra manera axí mateis fort espatxada, e no hi cal juristes; e que es aquesta: Lo cadí, ço es aquell qui te justicia, seu en cert lloch de la vila ab alguns saigs qui l'acompanyen. Si doncs tu vols proposar causa algú, tu ho dirás a la part, e dir li has aixi: -Vet que io vaig clamar de tu-. E ells han tanta de vergonya de venir davant la cort, que de continent te faran pregar, e pregará el mateix que no et clames, car ell se avendrá ab tu. Si tu no vols oir sos precs, ans dius que et vols anar a clamar, ell de continent per força te ha a seguir fins al jutge, car si ell no venia ab tu, puis tu provasses que lo hi haguesses dit, tantost serie assotat. Estant, doncs, tu e l'altre davant lo jutge e proposant ton clam, ell demanaria a l'altre si es ver ço que tu proposes. Si ell nega veritat e pot ésser jamés provat lo contrari, ell ha ésser assotat terriblement, tot nuu, gitat en terra boca avall, e ab nirvis de bous secs, deu pendre certs colps e grans davant tot hom. Aquí mateix, si atorga veritat e no el vols esperar, si nos diners deguts de present, o ell te ha de pagar, o ha a romanir aqui ab lo cadí, e cll romandrá e estará de present pres e será feta execució dels seus bens de continent, dels quals será pagat; e si no hi basten, parar-s'hi ha la sua carn. Si lo fet entre tu e l'altre es dubtós, tantost aquí mateix se ha a determenar sens tota dilació"

La escueta descripción de Eiximenis resulta lo suficientemente clara para comprender que era un sistema judicial rudimentario, pero que se complicaba con numerosas prescripciones de tipo procesal que se detallan en diversos tratados como el «Libre de la Çuna e Xara dels Moros», referente al procedimiento y normativa aplicable por los alcadíes valencianos en sus actuaciones".

La oralidad era el principio procesal más característico del enjuiciamiento que realizaba todo alcadí moro, aunque había situaciones en que se requería la transcripción de actuaciones en actas escritas, según ya se prescribía en las actas de nombramiento de los alcadías reales durante el siglo XIV. Así, en el nombramiento del alcadí de Guadalest, se le imponía:

e dels enantaments e processes que farás contra alcuns sarrahins, deies fer libre e

" Manuel Vte. Febrer Romaguera, Los Bellvís, ob cit. supra, pp. 277-29().

"Francesc líximfnis, Regiment de la cosa pública, Barcelona, 1927, pp. 154155.

"Libre de la Çuna e Xara dels Moros (Edición de Carmen Barceló Torres), Córdoba, 1989. 
memorial, perço que per aquells en son loch e temps pusca esser hauda informació dels enantaments, juhis e sentencies que darás, en qual manera será per tu en aquells procehit e enantat".

La tradición islámica imponía que las audiencias se realizaran en lugar público y concurrido, como las puertas de las mezquitas, al estilo de los antiguos cadíes de la aljama de Córdoba durante la época Omeya ".

Aunque hay ejemplos de audiencias en las propias casas de los alcadíes de Valencia y Xátiva, creemos que la tradición pesaba lo bastante como para preferir las puertas de las mezquitas, como bien demuestra la notificación mandada en 1445 por el comendador de Onda al baile general de Valencia refiriendo como:

Ali de Bellvis e de son fill, lo qual ací a la porta de la mesquita (de Onda), estant en johi, pronuncià ells semblants deure paguar lo bessant, VIII sous per casa, e X diners per un jornal ".

Es decir, que el alcadí general y su hijo (Mahomat de Bellvís), acostumbraban a tener audiencia en Onda, en la puerta de su mezquita, al menos durante la ocasión del litigio motivo de la misiva.

Dejando para otra ocasión los temas de procedimiento, nombramiento, sucesión y remuneración del cargo de alcadí, así como lo referente a sus competencias y atribuciones, debemos decir, que, el tribunal que ellos presidían se caracterizaba por una innegable simbiosis de características heredadas de la organización judicial islámica, y de elementos adoptados de la organización foral valenciana, como consecuencia inevitable de los largos años de dominación e intervención de la sociedad cristiana en la organización de las aljamas mudéjares" ".

\section{I.3. Alcadies auxiliares, sustitutos, asesores}

Pese a la vigencia del principio de unicidad de jurisdicción en manos de los

" ARV, Real, núm. 630, fol. 205 r.-v.

"Al.joXAni, Historia de los jueces de Córdoba (Traducción de Julián Ribera), Madrid, 1914.

"ARV, Batlia, Letres i Privilegis, núm. 1149, fol. 467 v.

"Remitimos a nuestro estudio: Manuel Vte. Febrir Romaguera, La justicia mudéjar en la Valencia foral, en "Estudios en homenaje a J.J. López Ortiz», Madrid, 1993. 
alcadíes, al menos a nivel teórico de la normativa islámica contenida en la "Çuna e Xara»; no se admitía más competencia para determinar las causas de la jurisdicción ordinaria (normalmente de carácter privado), que la de los alcadíes; aunque lo cierto era que, en la práctica, desde antiguo las cosas eran muy distintas. Ya desde el periodo de dominación islámica, se admitía y autorizaba el nombramiento de jueces auxiliares para la determinación de procesos que se ventilaban en ciertos lugares a los que no podía acceder ordinariamente el alcadí titular, por estar situados en zonas lejanas o por hallarse ausente de ellos el alcadí en determinado periodo ".

En la misma línea, ya conquistadas las tierras valencianas, en 1280 , autorizaba el rey Pedro III el Grande (I de Valencia), al alcadí de la morería de Valencia, Mahomat de Sale, a nombrar un «sustituto» o lugarteniente suyo cuando estuviese ausente del arrabal moro valenciano ${ }^{40}$.

Dada la proliferación de este tipo de cargos, se tuvo incluso que prohibir la multiplicación de lugartenientes de alcadí en la morería valenciana, estableciéndose en 1338 por Pedro IV que sólo se nombrase uno cuando el alcadí titular estuviese ausente del arrabal ".

El nombramiento de los jueces o alcadíes moros auxiliares o sustitutos competía ordinariamente al baile general de Valencia en el territorio de su jurisdicción, según provisión otorgada por el rey alfonso IV en 1330, en defecto del nombramiento que realizara el monarca ${ }^{42}$.

La misión de estos alcadíes auxiliares no era sólo la de sustituir a los titulares cuando se hallaban ausentes o no podían determinar ciertas causas, sino que sus cometidos se extendían al asesoramiento del alcadí cuando las circunstancias de la complejidad del caso lo requerían. En este sentido, encontramos alcadíes asesores en 1454 del alcadí de Gandía, al alcadí de Picassent y al alfaquí de Beniarjó, que habían sido requeridos por el Baile general de Valencia, Berenguer Mercader, en la causa que enfrentaba al moro Cacim Bianue, de Benirredrà, contra Ali Bohayaç, de Vall d'Alfandec ".

En otra causa surgida entre el alcadí Benzacharia de Elx y los adelantados de la aljama en 1459, el alcadí general Mahomat de Bellvís (I) determinaba el asunto asesorado por el lugarteniente de alcadí general Ali Coret, por el alcadí Ubecar de Gandía, y por el alfaquí Açen de la morería de Paterna, según había dispuesto el propio rey Juan II ${ }^{44}$.

Aparte de ser competencia del rey y del baile general el nombramiento de

") Émile TYAN, Histoire de l'organisation judiciaire, ob. cit. supra, pp. 214-219.

" ACA, CR, reg. 44, fol. $190 \mathrm{r}$.

"Ibid., reg. 862, fol. 119 v.

1: Aureum Opus, ob. cit. supra. Alfonsi Secundi. Priv. IX.

"ARV, Batlia. Letres i Priv., n. 1152 , fol. 884 v." 886 bis r.

"Ibid., Real, núm. 87, fol. 162 v.-163 r. 
estos alcadíes asesores, los propios alcadíes generales de la familia Bellvís detentaron tempranamente esta atribución, como se observa en 1350 que ya disponía Faraig de Bellvís, de un lugarteniente de alcadí en la morería de Valencia, en la persona de Fat Albarramoni ". Con el tiempo, lo que fue una autorización para nombrar sustitutos de los cargos que acumulaban los Bellvís en Aragón, Cataluña y Valencia, se convirtió en privilegio real de Juan II concedido a Mahomat de Bellvís (I) en 1458 y confirmado para él y sus sucesores por Fernando II el Católico en 1479.

En consecuencia, veremos a este Mahomat de Bellvís (I) nombrar diversos alcadíes en diferentes aljamas, como la de Tortosa, en la persona de Mahomat Saragoci (1475), y en la de Lleida, en la de Ali Amade Aycicot (1476) ${ }^{*}$.

Del mismo modo, Ali de Bellvís (II), alcadí general sucesor de su padre Mahomat, nombraría lugarteniente de alcadí suyo en la morería de Xàtiva a Abdallá Alcamba, con la obligación de responderle cien sueldos anuales, parece ser, en calidad de arrendamiento del cargo ".

Respecto a los alcadíes auxiliares de los alcadíes de señoríos posecdores del mero imperio, pensamos que la competencia para su nombramiento debía pertenecer al señor, igual que solía atribuírsele el nombramiento de alcadíes, a tenor del privilegio real ótorgado en $1330^{4.4}$.

\section{I.4. Los alfaquies}

Se conocía comunmente como alfaquíes (=faqihs, en árabe), a las personas entendidas en la ley islámica, que contaron con un notable prestigio en la España musulmana, por sus numerosas funciones jurídicoreligiosas.

Entre sus funciones judiciales, destacaba la facultad para emitir dictámenes jurídicos (fatwā), a requerimiento de parte o de alcadí, con un valor de prueba legal en juicio, semejante a la antigua «responsa prudentium» de los juristas romanos. El ejercicio de esta atribución llamada "futya», era una actividad gratuita que daba a los alfaquíes del periodo de dominación musulmana un prestigio y consideración importantes, social y políticamente, según su categoría personal y técnica. Aunque no podían percibir remuneración pecuniaria, si podían recibir regalos en especie, los cuales frecuentemente, por

"Ibid., Protocolos. Bernat de Calp, núm. 2959, fol. s/n."

" Ibid., Protocolos. Johan de Campos (minor), núm. 442, fol. s/n."

" Ibid., Batlia. Letres i Privilegis, núm. 1157 , fol. 155 r.-156 r. y 307 r.-v.

t* Ibid., Real, núm. 630, fol. 201 r.-204 r. 
lo sustenciosos, les daban una posición de personas opulentas. Los más célebres alfaquíes en la formulación de dictámenes se codeaban con emires, califas, cadíes y toda clase de jerarquías del estado, recibiendo la denominación de "muftis». Su actuación independiente, digna y de intachable moralidad, les hacía aparecer ante el pueblo musulmán, cuando concurrían tales cualidades, como modelos de conducta, siendo elevados a dignidades religiosas, al asignárseles la dirección de la oración y predicación en las mezquitas frecuentemente ${ }^{40}$.

Alfaquíes célebres de Valencia durante el periodo de dominación musulmana fueron Al-Faradì (s. XI), Ibn Baškuwāl (s. XI-XII) y Ibn Al-Abbār (s. $\mathrm{XIII}$ ), entre otros, todos los cuales ejercieron además de las funcionés religiosas mencionadas, la de emisión de dictámenes jurídicos (fatwā), redacción de actas jurídicas como notarios, asesoramiento de alcadíes en los juicios que se les requería, y otras funciones políticas a solicitud de los sultanes. También se les veía ejercer el comercio y diversas actividades sociales. Algunos llegaron a alcanzar la dignidad de cadí de Valencia ".

A nivel local, los alfaquíes fueron los personajes que se nombraban en las mezquitas para la atención del culto, explicación de la ley y atención a las diversas funciones mencionadas de carácter judicial (consilium, responsa, documentación de actos jurídicos, etc.).

El aspecto de funcionarios de las aljamas que tuvieron los alfaquíes del periodo islámico, se conservó más o menos durante la época mudéjar, al requerírseles su intervención frecuente en la redacción de actas de toda clase de negocios jurídicos como escribanos de las localidades; así como asesores judiciales de los alcadíes y formuladores de dictámenes jurídicos.

En este sentido, observamos frecuentemente que el baile general de Valencia demandaba el asesoramiento de alfaquíes, cuando el alcadí general del reino tenía que resolver algún asunto complejo. Así lo vemos en procesos como el seguido por el alcadí real Mahomat de Bellvís (I) ante la bailía general, en 1459, entre los moros Abrahim Bendorim, de Betxí, y Yaye Cocentaini, de Manises, en el que actuaban como asesores, aparte del lugarteniente del alcadí general, Ali Coret, el alfaquí de Segorbe, Ali Abarrabe, el alfaquí de Benaguasil, y el de Betera, llamado Abdulaziz".

w A.M. TURKI, La vénération pour Malik et la physionomie du Malikisme andalou, en "Studia Islamica", 33, pp. 58. - H. MONES, Le rôle des hommes de religion dans l'bistoire de l'Espagne musulmane jusqu'à la fin du Califat, en "Studia Islamica», 20, pp. 47-88. - Émile TYAN, Histoire de l'organisation judiciaire, ob. cit. supra, PP. 225 y 234.

"1) Rafael CASTEjón CALDERÓN, Los juristas hispano-musulmanes desde la conquista, hasta la caida del Califato de Córdoba: 711-1031 de C., Madrid, 1948. Dominique Urvor, Le monde des ulémas andalous du VIVI au VII/XIII siècle, Ginebra, 1978, pp. 73.

"ARV, Batlia. Letres i Priv. núm. 1152, fol. 1717 v. 
El baile general de Valencia tenía facultades para nombrar estos asesores del tribunal del alcadí, pues a requerimiento del alcadí general Mahomat de Bellvís (I), en carta fechada en 1451, se le suplicaba al baile general Berenguer Mercader:

soplich a vostra senyoria, a vos placia trametre'm a l'alfacuí de Paterna he al de la moreria, ho alguns moros dels millors de aquexa moreria, aquells (que) la vostra senyoria haurà per bons, per que sien presents en la determinació de la sentencia (e) execusió,

la cual se seguía en Vall d'Uixó, en un proceso por asesinato. El mismo día del dicho requerimiento, respondía el baile general a su lugarteniente de baile local en la referida villa, que enviaba una serie de personas «moros de la dita moreria promens e bons homens», a fin de que se realizara el referido proceso y sentencia".

En 1460, se observa un proceso de apelación seguido en Vall d'Alfandec, entre el alfaquí Çalema y la aljama del lugar denominado a la sazón «La Umbria», sito en el mismo valle, que ya había sido sentenciado por el alcadí de Gandía y el abad de Valldigna. El proceso de apelación se veía en la bailía general por el alcadí de Xàtiva aconsejado por Ali Coret, lugarteniente del alcadígeneral, quienes pronunciaron sentencia definitiva en el sentido de que la aljama de La Umbria debía nombrar otro alfaquí para hacer la azalxà, debiendo abandonar la población el revocado alfaquí Çalema. Con ello, se ve clara la competencia de las corporaciones mudéjares o aljamas para proveerse de alfaquíes que se ocupasen de las atribuciones religiosas entre las demás propias del cargo".

En cuanto a las funciones de escribano que se asignaban a los alfaquíes, parece que necesitaban de nombramientos más formales, que debían ser semejantes al del alfaquí nombrado en Segorbe en 1431, en la persona de Hamet Alvalenci, el cual contenía la facultad para ejercer la función de fedatario y autentificador de los documentos privados que se otorgaban entre moros.

Según este nombramiento, y la documentación consultada, resulta difícil distinguir entre el oficio de alfaquí y el de escribano de las aljamas, ya que solían ir frecuentemente emparejados; por ello, las atribuciones notariales que se atribuían a los referidos escribanos moros, eran semejantes, en cuanto se refiere a la autorización de documentos, a las funciones que ejercían los alfaquíes. Su labor se limitaba en la esfera de documentación, a certificar instrumentalmente en árabe las disposiciones o estipulaciones verbales de los

$\because$ lbid., núm. 1151, fol, 198 r.-v.

"Ibid., núm. 1153, fol. 14v.-15r. 
particulares, actuando como testigos que redactaban una prueba documental ante terceros o en juicio. La justicia foral valenciana, solía admitir como válidos estos documentos de los alfaquíes, como si fueran documentos notariales, refiriéndose frecuentemente a procuraciones, cartas dotales, donaciones, herencias y otros documentos diversos. Tanto podían redactarse por alfaquí como por alcadí, siguiendo por lo general las fórmulas usuales heredadas de los formularios de la época de dominación islámica. Tal como requería el derecho musulmán, solían estar corroborados por dos testigos, que eran los que en realidad testimoniaban la validez del documento.

La aceptación de estos documentos por la bailía general en los procesos elevados a acta en sus libros, nos ha ofrecido la oportunidad de conocer sus fórmulas y contenido, dándonos a entender la conservación de las prácticas del periodo de dominación islámica ${ }^{4}$.

Con la aculturización creciente de la comunidad mudéjar valenciana, los moros fueron requiriendo progresivamente la presencia de los notarios cristianos en sus relaciones con los cristianos, aunque conservaron a sus alfaquíes para la redacción de los documentos más típicamente de la esfera privada, referentes a la familia y propiedad, que afectaban sólo a moros. Sin embargo, encontramos algún ejemplo de redacción de contratos matrimoniales ante notarios cristianos, como es el caso del firmado en 1465 entre el alfacuí de la morería de Valencia, y el alcadí de Vall d'Uixó, para casamiento de este último con Fátima, hija del predicho alfaquí; documento que fue redactado por el notario Johan de Campos, titular de la notaría de la bailía general de Valencia.".

Los nombramientos de alfaquíes debieron reservarse en principio a las propias aljamas, aunque con el tiempo debieron introducirse mecanismos de intervención de la Corona, sus oficiales o los señores, en caso de aljamas de señorío. En el caso del nombramiento del escribano-alfaquí de Segorbe, se hizo seguramente a propuesta de la aljama. Esta propuesta se presentaba al baile general de Valencia, por pertenecer la ciudad en estas fechas al rey; y el baile general, realizaba el oportuno nombramiento del alfaquí local detallando sus funciones de escribano de la aljama. El dicho baile, tras consultar al alcadí de Benaguasil, Mahomat Abenamir, en calidad de mayor de los que existían en las tierras del ex-conde de Luna, dió por revocado el antiguo escribano alfaquí de

"ABenmoguit, Formulario notarial, en "Anuario de Historia del Derecho Español», VII (1931), pp.l y ss. También Carmen BARCrió TORRES, Minorias islámicas en el País Valenciano: Dialecto e historia, Madrid-Valencia, 1984, en su colección documental de textos árabigo-valencianos traducidos nos ofrece una oportunidad de comparación importante entre los formularios clásicos de documentos del periodo musulmán y los documentos mudéjarcs.

"ARV, Batlia. Plcits, núm. 1438, fol. s/núm. 
Segorbe nombrado por el referido Mahomat Abenamir, otorgando el nombramiento al propuesto por la aljama ".

En cuanto a los dictámenes jurídicos que emitían los alfaquíes, en atribución compartida con los alcadíes, se observa con frecuencia que ésta era una práctica usual en la mayor parte de causas complejas que se ventilaban ante los alcadíes generales, que eran los que solían determinar los asuntos de mayor dificultad, por referirse a la esfera criminal sobre todo. Por otra parte, el requerimiento de este tipo de dictámenes no estaba al alcance de todos los litigantes. De este modo, en 1452, vemos al alfaquí de Beniarjó y al de Paterna, dictaminar sobre el derecho que tenía el moro de Valencia llamado Mahomat Ziquell, a adquirir la propiedad de cierto campo comprado a un moro de Tavernes de Valldigna".

\section{I.5. Procuradores de pleitos}

Como había ocurrido durante la época de la dominación musulmana, durante el periodo mudéjar, cualquier pleiteante podía defenderse en la audiencia personalmente o mediante un procurador de pleitos (Wakil), a fin de evitar la vergüenza que sentía de comparecer en el tribunal del alcadí.

Los procuradores de pleitos eran una especie de abogados o procuradores de tribunales «mandatarios judiciales», que dada su calidad de juristas, eran encargados de la defensa de sus intereses por su respectiva parte.

Aunque los incapacitados para comparecer en juicio, según la ley islámica (mujeres, impúberes, infieles y esclavos), debían ser defendidos por sus representantes legales, éstos no tenían la consideración de procuradores de pleitos; ya que el nombramiento de tales colaboradores o mandatarios era libre por cada una de las partes. No obstante, los alcadíes estaban facultados para restringir su nombramiento, sobre todo en causas manifiestamente injustas, según su arbitrio.

El acto del nombramiento del procurador de pleito podía hacerse por simple declaración verbal del mandante ante el alcadí estando en audiencia y en la presencial del mandatario-procurador. En alguna ocasión, la constitución de procurador defensor se solía hacer mediante acta escrita ante alfaquí o escribano moro, igual que la revocación de su nombramiento.

El papel del mandatario judicial-procurador de pleitos, se extendía a todo tipo de procesos, y sus poderes dependían de las condiciones del nombramiento

"Ibid., Batlia. Letres i Priv., núm. 1152, fol. 528 v.-529 r.

"Ibid., núm. 1151, fol. 606 v. 
otorgado por el mandante. El mandato podía ser gratuito u oneroso, en cuyo caso último podían observarse diversos sistemas de remuneración.

El mandato se extinguía por revocación del mandante, muerte de una de las partes, aunque, si había herederos del mandante, el mandatario podía acabar su encargo si faltaba poco para finalizar el asunto, siempre en provecho del causahabiente del difunto cumpliendo su encargo. La revocación, sólo podía hacerse por falta grave del mandatario, y aún en este caso no se permitía revocar el mandato, si estaba a punto de cumplirse. Incluso el alcadí podía revocar un mandatario, en caso de que el mandante actuara de mala fe.

Algunos autores de la escuela malikí, decían que, después de transcurridos seis meses desde la constitución del mandato sin alcanzarse cumplimiento, éste perecía, y el mandatario que quisiera proseguir su cometido debía obtener una renovación del mandato procuratorio ".

La perduración de la práctica procesal de utilización de procuradores de pleitos, perduró bastante restrictivamente en el periodo mudéjar, ya que la normativa recogida en el «Libre de la Çuna e Xara de Moros», obligaba a comparecer personalmente en juicio a todo moro citado por la otra parte; diciendo:

Si algún sarrahi del qual algú se serà clamat e serà citat o amonestat per l'alcadí, a instància del clamater, que vinga a fer dret davant aquell clamater, e no volrà comparer, aquell aital, segons Çuna, per la dita inobediència, a coneguda de l'alcadí o del senyor, deu ésser punit".

Sin embargo, las mujeres y personas ausentes eran ordinariamente representados en juicio por procuradores de pleitos, nombrados en actas redactadas por alfaquíes y alcadíes, que eran oportunamente presentadas ante los tribunales. De dicho modo, comparecían en 1430 ante el tribunal cadial formado por el baile general Johan Mercader, los procuradores Ali Acen y Galip Cefuan, que representaban los intereses de varios moros ausentes procesados por la bailía general. En el acto de acreditación de su poder, presentaban el acta escrita «en morisch» redactada por escribano moro, que traducida al romance se copiaba en las actas del proceso, admitiéndose la validez de sus actuaciones judiciales en defensa de los ausentes "'t".

En pocas ocasiones vemos actuar este tipo de procuradores de pleitos, pero, los escasos testimonios prueban que se les permitía actuar sólo excepcionalmente.

s* Emile TYAN, Histoire de l'organisation judiciaire, ob. cit. supra, pp. 262-275.

"Libre de la Cuña e Xara dels Moros, Cap. CCCXV.

(1) ARV, Real n." 625, fol. 91 v. 


\section{LOS AUXILIARES DE LA «CORT DE L'ALCADÍ»}

\section{II.1. Los "escribans»}

El tribunal cadial de la época musulmana se caracterizó siempre por su sencillez y parquedad de funcionarios judiciales, limitándose los cadíes más importantes, como los de Córdoba en la época Omeya, a disponer de un secretario (katîb) y algún alguacil (šurtî), aparte de que se llamara ocasionalmente a algún que otro alfaquí para asesoramiento en determinadas causas ". Esta tradición de sencillez fue recogida por los alcadíes valencianos del periodo mudéjar, llegando incluso a contar con secretarios del tribunal. De este modo, los alcadíes solían acumular el cargo de escribano de la corte judicial, como bien reconocía en 1280 el rey Pedro III al alcadí de la morería de Valencia; Mahomat de Sale, al conferírsele la posesión del cargo de «escribanus» de su misma corte; seguramente para arrendar el cargo o concederlo a su beneplácito a persona de su confianza, aunque en ocasiones debía ejercer las funciones de la escribanía el propio alcadí ${ }^{\prime 2}$.

Los alcadíes generales de los siglos XIV y XV no solían auxiliarse de escribanos en sus audiencias, pues ellos mismos detentaban el oficio, según antiguas concesiones reales; aunque, en determinados casos, podían nombrar distintos lugartenientes de escribano para el ejercicio efectivo del cargo ".".

En cuanto a los cometidos que usualmente se les encargaba, los escribanos de las cortes de los alcadíes se encargaban de la redacción de distintos documentos, entre los cuales las cartas matrimoniales, dotales, compraventas, donaciones, testamentos, procuraciones de pleitos, divisiones de herencias, y otros tipos de documentos privados, conforme a las fórmulas tradicionales heradadas de la época islámica, tal como nos dan a entender los ejemplos conservados en traducciones valencianas. En no pocas ocasiones, los alfaquíes de las morerías acaparaban también el cargo de escribano, siguiendo una tendencia que ya remontaba al periodo de dominación musulmana, que se continuó durante los siglos XIV y XV. Sus documentos se redactaban en árabe, habiendo llegado algunos hasta nosotros "1.

". J.J. LÓpez ORTiz, Derecho musulmán, Barcelona, 1932, pp. 75-77.

(2) ACA, CR, reg. 44, fol. 19() r.

"ARV, Protocolos. Joan de Campos (minor), núm. 442, fol. s/n."

(1.) ARV, Batlia. Letres i Priv., núm. 1152, fol. 959 v.-960) v. En el acta del nombramiento del alfaqui-escribano de Segorbe, Hamet Abarrabe (1454), se le asignaban estas competencias: "recipere, condere et testificare ut per dictam çunam et xaram fieri 
Su principal cometido judicial era la redacción de las actas de los procesos, de las cuales podían pedir las partes copias, por las cuales recibían determinada remuneración, según se detallaba en el acta de nombramiento del escribano de Segorbe nombrado en 1454 por el rey Juan de Navarra, lugarteniente general del reino, en la persona del moro Hamet Aberrabe, a propuesta del alcadí moro de Benaguasil, Hamet Abenamir, que a la sazón ejercía el cargo de alcadí mayor del antiguo condado de Luna ${ }^{65}$.

De la lectura del referido nombramiento y de la práctica observada, resultaban los escribanos tanto cargos judiciales como extrajudiciales, por eso acumulaban cometidos que excedían a los de meros auxiliares de los alcadíes, ejerciendo en otros campos cometidos autónomos.

\section{II.2. Los «torcimanys»}

El "torcimany» de la corte del alcadí valenciano, al igual que el «trujamán» de las morerías aragonesas, era un intérprete al servicio de los alcadíes, con semejantes características que los existentes en las aljamas.

Eran oficiales auxiliares de carácter ocasional, nombrándose por los alcadíes cuando algún testigo no era entendido por no hablar la lengua árabe, o porque hablaba otra lengua desconocida por el presidente del tribunal. El cargo se remontaba a antiguos precedentes detectados durante el periodo de domina-

\footnotetext{
solitum est, cartas seu instrumenta dotalicia si(ve) de acidachs et cuibuslibet alias scripturas publicas et autenticas dumtaxat in dicte civitate Sugurbii, eius morerie et terminis eiusdem et eos scribere facere per illos agarenos quos duxeritis eligendos, dum tamen in eisdem ut scribe confiteatis te intervenisse quibus fides in judicio et extra inter dictos agarenos adhibeatur, et faciente de predictis scripturis illa capibrevia sive notas que per dictam şunam et xaram alii scribe talia oficia exercentes soliti sunt recipere".

6s ACA, CR, reg. 2223, fol. 110 v.-111 v. Consta según M." Teresa Ferrer Mal.lol, Les aljames sarraines de la Gobernació d'Oriola en el segle XIV, Barcelona, 1988, p. 64; que en 1407 ya era un Abdalla Abenamir alcadí de las aljamas de Segorbe, Serra d'Eslida, Vall d'Uixó, Vall d'Almonacid, Vall de Seta, Vall de Travadell, Paterna, Castro, Elx, Crevillent i Benaguasil, patrimonio integrado en el de los reyes Martín y María de Luna. Este cargo lo detentaba con carácter vitalicio, concediéndosele el 16 de febrero de 1407, el derecho a designar sucesor a un hijo suyo llamado Abhaquem Abenamir, a título vitalicio. Josep NiCOlau I BAuzà, Págines de la bistòria de Benaguasil, Benaguasil, 199(), p. 77 y ss. ofrece importantes datos documentales sobre la familia Abemamir durante los siglos XV y XVI, que denotan su importancia religiosa y económica en todo el territorio del llamado «Antich Patrimoni del Comtat de Luna»
} 
ción islámica, en que los cadíes podían disponer de «tarŷumān» (=intérpretes), cuando comparecía en juicio alguna persona no arabigoparlante ".6.

Estos cargos debieron ser particularmente abundantes en la época inmediata a la conquista cristiana, haciéndose cada vez más raros con el transcurso de los años, al ir conociendo los alcadíes cada vez mejor las lenguas romances habladas en el reino valenciano, al igual que los pobladores moros.

El conocimiento de los romances por los alcadíes valencianos está atestiguado desde el mismo siglo XIII, al encontrar ejemplos como el del alcadí de Cocentaina que en 1275 ya pronunciaba una sentencia en romance, en un litigio entre moro y cristiano, presente el justicia y un jurado local ". En otra ocasión, encontramos años después al alcadí de la morería de Valencia, Mahomat Abenguabarrig, actuar como traductor al romance de un documento arábigo (1298) ${ }^{\text {c. }}$.

De este modo, los propios alcadíes asumían el cargo de traductores en los juicios que determinaban. En este sentido, encontramos en 1430, que el lugarteniente de alcadí, Mahomat Alestandar, natural de la morería valenciana, actuaba como traductor de un acta de procuradores de pleito presentada en un proceso que se veía en la bailía general de Valencia ".".

En 1481, el alcadí general Mahomat de Bellvís (I), sería nombrado por Fernando II el Católico, "torcimany" oficial de la corte de la bailía general de Valencia, confirmando formalmente en un privilegio la práctica que se había venido dando desde hacía bastantes años. En consecuencia, encontraremos frecuentemente ejemplos de intervenciones de los alcadíes generales en los procesos contra moros que se ventilaban ante la corte de la bailía general, como es el caso de cierto pleito surgido en 1502, en el que el alcadí general Ali de Bellvís (II), intervenía como traductor de una carta dotalicia escrita en arábido, que se presentaba por las partes en juicio. Según decía el documento, se trataba de: "un acte de acidach splanat per lo scrivá de la cort ab intervenció d'Ali Bellvís, alcadí del Senyor Rey" ".

"E. TYAN, Histoire de l'organisation judiciaire, ob. cit. supra, p. 258.

(1) Archivo Municipal de Cocentaina. Cort del Justicia: 1275-1276, fol. 26 v.

6. ARV, Clero-Valldigna, leg. 781. Pergamino suelto. (Publ. Ferran García-Ol.IVER, El naiximent del monestir cistercenc de la Valldigna, València, 1982, doc. 2. También por $\mathbf{M}$. Vte. Febrer Romagurra, Cartas pueblas de las morerias, ob. cit. supra, doc. 70).

69 ARV, Real núm. 625, fol. 91 v. y 100 r.

70 Ibid., Batlia. Letres i Priv., núm. 1157, fol. 307 r.-v. También: Ibid., Batlia. Pleits, núm. 1433, fol. s/n." 


\section{II.3. El "f̧almedina"}

El cargo de zalmedina (çalmedina o çatmedina), se remontaba al periodo de dominación islámica, en que los «sāhib al-madina» (=jefes de policía de la ciudad), fueron los funcionarios represivos de la justicia, encargados de la ejecución de las disposiciones judiciales y del castigo y prevención de las alteraciones en el orden público, ayudados por diversos policías auxiliares (šurtî), conforme a las prescripciones de la jurisdicción de represión de los abusos (šurta)".

La desaparición o merma de los principales núcleos urbanos islámicos valencianos tras la conquista cristiana redujo el número de zalmedinas a un reducido número, localizado en determinadas morerías, tales como la de Xàtiva, Cocentaina y Horta d'Alacant, entre otras que no conocemos.

Existen escasas noticias de los zalmedinas de la gobernación de Orihuela, habiéndose hallado referencias sobre el del Valle de Elda y el de Aspe. Parece ser que el zalmedina de Elda, entre el cometido de ejecutar las sentencias y disposiciones del alcadí, tenía el de denunciar ante su corte los delitos, actuando como un procurador fiscal moro, al menos en el siglo XIV. Pero como consecuencia de la intromisión del procurador señorial en el nombramiento de un zalmedina cristiano en Elda, la aljama elevó quejas a la reina Violante de Bar, señora del valle, a fin de que se respetaran las atribuciones del zalmedina moro que tenían, como sus privilegios les había

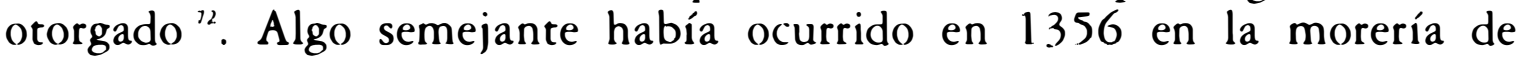
Xàtiva, en la que un cristiano había obtenido el nombramiento de zalmedina de la morería, lo cual motivó una queja de la aljama al rey Pedro IV, el cual en provisión prohibió que dicho oficio fuese ejercido por cristianos, debiendo nombrar el baile general de Valencia a moros de la propia morería setabense, según las atribuciones reconocidas en su carta puebla de 1252 ".

El zalmedina moro de Xàtiva, según este privilegio de población del arrabal moro, tenía una atribuciones concretas:

...̧̧atmedina faciat iustitias et districtus inter vos, excepta tamen morte hominum, et

"Ambrosio Huici Miranda, Historia musulmana de Valencia y su región, Valencia, 1969, I, p. 49. También, Évariste LEVi-PROVENÇAL, España musulmana. Instituciones y vida social e intelectual, en "Historia de España" dirigida por R. Menéndez Pidal, V (II), pp.87-90. También E. TYAN, ob.cit., pp. 567-568.

'2 M. Teresa FERrer I MAllol, Les aljames serraïnes, ob. cit. supra, pp. 78.

" ACA, CR, reg. 966, fol. 89 r. (Publ. M. Vte. Febrer Romaguera, Cartas pueblas de las morerias, ob. cit. supra, doc. 192) 
quod dictus f̧almedina ponat exortivos quoscumque ponere voluerit ad iustitiam exercendum..., et quod çalmedina teneat alhafiç supradictum; et habeat decimam partem caloniarum pro labore suo...

...Statuentes quod si aliquis christianus conqueratur de sarraceno, recipiat iustitie complementum in posse çalmedina vestre, secundum f̧una sarracenorum.

Como se puede observar, el zalmedina de la morería de Xàtiva reunía además de la función de consejero del alcadí, la de ejecutor de sus resoluciones, represión de abusos, y defensor de los moros en las causas que les enfrentasen son los cristianos ${ }^{74}$. Aparte, así como ocurría en Elda, encontramos que actuaban de denunciantes de los hechos criminosos, como procuradores fiscales de la corte del alcadí local "s.

Los ejemplos de nombramientos de zalmedinas en Xàtiva se extienden desde el siglo XIII, con el acta del otorgamiento del cargo al moro Abdulhabeb Albini, por el propio rey Jaime I (1275) ${ }^{7}$. Aparte de otros varios nombramientos durante el siglo XIV, puede citarse el de Ali Çabato, realizado en 1435 por el baile general de Valencia, Johan Mercader, con el salario de treinta sueldos anuales, percibibles del importe de los devengos de justicia de la corte del alcadí de Xàtiva ".

Sin embargo, la naturaleza del cargo y la falta de difusión del mismo, lo hacía de carácter excepcional; a pesar de lo cual en 1431,1459 y 1468 , se intentó implantarlo por la administración real en las morerías de Orihuela, Monforte del Cid y Alcoi, al proyectarse la reconstrucción de las mismas. En el caso de Alcoi, sólo se pretendía nombrar un Zalmedina «apellat missatge, per executar los manaments» de los adelantados y aljama, funciones muy alejadas de las de auxiliar del alcadí ${ }^{\prime 8}$.

En las morerías que no existía zalmedina; sus funciones principales se asumían por los alguaciles o policías llamados «xurtins».

$"$ Ibid., Cartas pueblas de las morerias, doc. 11.

'ARV, Mestre Racional, núm. 3()12, fol. 13 r. y ss.

"ACA, CR, reg. 20, fol. 27() r. El cargo se otorgaba por la Corona: "sicut zalmedine sarracenorum ravalli Sative ipsum officium in Xativa melius exercere consuevit. It habeas inde pro officio et labore tuo ca iura que calmedine Xative inde recepits.

ARV, Batlia, Lctres i Priv., núm. 11.48, fol. 126 r.

"s ARV, Batlia, Letres i Priv., núm. 1154, fol. 22) r a 232 r. (publ. Ricard BANYó I Arminyana, La morería de Alcoi, en "Ciudad», dia 3()-VI-1979); p. 13; día 3-VII-1979, p. 8 ; i dia 5-VII-1979, p. 10).

Las cartas pucblas de Monforte del Cid (ARV, Real, núm. 283, fol. 186 v.-189)r.) y de Orihuela (Archivo) Municipal de Orihucla, Libro de Privilegios, fol. 198 v. 199 r. Ibid, Actas - Capitulares. Arm. I, n. 21 (1431), fol. 116 r.-117v.), se hallan en nuestra inédita tesis doctoral leida el 27-VI-1984, y se publicarán en breve. 


\section{II.4. Los "xurtins»}

Los policías judiciales, denominados durante la época de dominación islámica "šurti», dieron lugar a los denominados en la documentación cristiana del periodo mudéjar "xurtins» (exortivos, exortinos, captiones, saigs, o sagiones).

Eran auxiliares de la represión de abusos, estando normalmente a las órdenes de los zalmedinas, donde los había. Donde no existían zalmedinas, los "xurtins» se encargaban de sus principales cometidos de auxilio de la justicia. De este modo, sus cometidos se extendían a la persecución, apresamiento, encarcelamiento y denuncia de los delincuentes ante la corte del alcadí o demás cargos que tuviesen encargado el ejercicio de competencias judiciales.

Eran una especie de funcionarios públicos al servicio de la administración judicial y municipal. Aparecían formulando denuncias, como los zalmedinas tanto ante alcadíes como ante el baile local, aunque el zalmedina de Xàtiva estaba dotado con una mayor amplitud de atribuciones que los simples "xurtins", al ser "procuradores fiscales de la corte del alcadí», según un régimen privilegiado no compartido por otros zalmedinas, salvo casos excepcionales.

A requerimiento del alcadí, baile local o incluso de los jueces delegados señoriales, o de los propios señores territoriales, se encargaban de realizar bandos, citar a las partes a audiencia pública, convocar a los testigos y publicar edictos judiciales requiriendo a los deudores para que pagaran en los plazos legales sus deudas, si no se quería que se procediese al embargo en caso de no realizarse el pago en el plazo de diez días.

Los "xurtins» o sayones (saigs), como auxiliares judiciales, eran los que inventariaban los bienes de los deudores y los ponían en pública subasta, dirigiendo las pujas generalmente mediante la intervención de corredor público.

La ejecución de las sentencias penales (azotes, mutilación, destierro, horca o lapidación), se hacía tradicionalmente por los propios sayones, aunque con la proliferación del verdugo público llamo "botxí» o "morro de vaques», fue limitándose su intervención a la conducción de los reos al sitio de ejecución.

A pesar de que los zalmedinas de Xàtiva se nombraban por la administración real (rey o baile general de Valencia), los sayones solían nombrarse por las propias aljamas, pero en Xàtiva se dejó estipulado en el privilegio real otorgado en 1252 para la repoblación de la morería que serían nombrados por los zalmedinas ".

1) M. Vte. Febrer Romaguera, Cartas pueblas de las morerias, ob. cit. supra, doc. 11. Los "captiones", "exortivos" y "albafic" que cita la carta puebla de la morería de Xátiva, no parecen más que sayoncs (saigs) auxiliares del zalmedina para la prepresión de abusos y ejecución de las resoluciones judiciales. 
II.5. Otros auxiliares judiciales: "carceller», "botxi" o "morro de vaques"

Como sus nombres indican, los presos en las cárceles eran custodiados por auxiliares llamados "cancellers", que cobraban por su labor una remuneración llamada "carcellatge», la cual solía ir a cargo de los presos. Solían ser personas cristianas, ya que se desconfiaba de los propios moros como custodiadores de sus correligionarios.

Los verdugos (botxins) o ejecutores de las penas corporales, solían ser personas conversas, con pocos escrúpulos para aplicar tormentos y penas crueles, tan típicas de la penalidad foral valenciana. Dada la dificultad del cometido, parece un cargo limitado a determinadas cortes de justicias cristianos, como la de Valencia (justicia criminal), en cuyo tribunal se instituyó el oficio llamado «morro de vaques», seguramente por el tipo de látigo que usaba con los reos. Cuando era precisa su actuación en alguna corte de alcadí para aplicar alguna pena corporal, se le llamaba a Valencia, acudiendo a realizar la ejecución y a cobrar su labor, como encontramos que se hizo en 1458 en Llombai por el verdugo Johan de Fuentes ${ }^{\text {"0 }}$.

no Archivo de Protocolos del Colegio del Corpus Christi. Manuel d' Esparça. Any 1458 fol. s/n." - Sobre el oficio de carcelero en la administración de justicia valenciana y los sayones puede verse: Francisco Roca Traver, El justicia de Valencia: 1238-1321, Valencia, 1970, pp. 129 y 173.

Sobre el verdugo o "botxím: Vicente Graullera SANZ, El verdugo de Valencia en los siglos XVI y XVII: Ejecución de sentencias, en «Estudios de Historia de Valencia», Valencia, 1978, pp. 203-214. 


\section{DOCUMENTOS}

132(), marzo, 11, Valencia.

Bernat Çanou, baile general de Valencia, nombra alcadi de Morvedre y su término al moro Azmet Elbono.

ARV, Real, núm. 630, fol. 200 r.

Als amats los serrahins habitants en Murvedre e en son terme e lochs e alqueries de realench, de mi en Bernat Çanou, batle general del regne de València per lo senyor Rey, saluts.

Faç vos saber que yo he comanat a Azmet Flbono, serrahí de Petrés, lo offici de alcadí en Murvedre e en son terme, axí que ell hoia e determén segons çuna tots los pleyts e contrasts que seran entre vós e encara que ell sol e no altre faça e scriva çidachs e altres cartes e contractes que seran entre serrahí e serrahí en lo dit loch de Murvedre e en son terme. Per què de part del senyor rey vos dich e us man, e de la mia vos requir, que lo dit Azmet Elbono haiats e tingats per alcadí vostre e a aquell obeescats e responats de totes aquelles coses de les quals devets e havets acostumat de respondre als alcadís e ab aquell façats çidachs e altres contractes que seran entre vós. E de part del senyor rey per la present dich e man a $n$ Guillem Folcan, lochtinent del batle general en Murvedre, e de la mia lo requir que lo dit Azmet haia e tinga per alcadí dels damunt dits sarrahins e a aquell don favor e ajuda degudament en lo dit offici tota ora que per aquell ne serà request. E encara do licencia al dit Azmet, que si los sarrahins dels lochs dels cavallers o alcun de aquells volran oir o estar al juhí del dit Azmet sobre lurs questions o contractes, que. I Azmet pusca aquells hoir odetermenar.

Data Valentic, V." idus martii, anno Domini M.".C.C.. XV IIII.". 
[1430, noviembre, 1, Vall d'Almonacid]

Yucef Abunacer y otros moros nombran procuradores de pleito para defender sus derechos ante juicio en Onda, a los moros Galip Benzuleymen Bencifran y Hali Benhacen Benibale.

ARV, Real, núm. 625, fol. 91 v.

En nom de Déu Piadós, fan procuració Yucef Abunacer e Çaat Benjale e Abdalla Bancala a los hereus de Zuleymen Abdorramen e Çaat Pollini e Benihaye Arapel e Çaat Solas e Çahet Alabiar, a Galip Benzuleyman Bencifran e Hali Benhacen Benihale, per demanar totos los drets a ells pertanyents en la terra que han en lo terme de l'Ondar, e pledejat per ells, e axi de atorgar com de negar tot ço que sia necessari en lo pleyt ho hajen a mostrar davant los jutges procuració bastant ab plen poder, axi con si ells fossen presents. E aceptaren los dits procuradors Galip e Ali la dita procuració de aquells, e que demanarien per lo dret de aquells axí com los seus.

Testimonis foren a la dita procuració que oyren dels sobredits com feyen procuració a aquests nomenats, e tots en sanitat e bon passament, en dia de dilluns en la darreria de octubre de l'any morisch huytcents trenta quatre:

Azment Benmahomat ben Çahet e Cilim Banali Benyacop.

Ferma la dita procuració Çuleymen Benabrahim Bençahet.

1431, marzo, 23, Valencia.

Johan Mercader, baile general de Valencia, nombra a Hamet Elvalenci, alfaqui de la moreria de Segorbe, escribano de la misma.

ARV, Batlia, Letres i Privilegis, núm. 1151, fol. 528 v.-529 r.

De nós, En Johan Mercader, doctor en leys, conseller del senyor rey e batle general del regne de Valencia, haven special manament e càrech per lo dit senyor rey a regir a guardar la terra qui fon de don Frederich, olim compte de Luna, als amats, jurats e aljama dels moros de la moreria de la ciutat de Sogorp.

Per les presents vos fem a saber que nós havem scrit a Mahomat Abenamir, alquadí de Benaguazir e de la dessús dita terra, sobre la comissió que demanats que fos feta a Hamet Elvalencí, alfacuí de aqueixa moreria, de la scrivania de aquexa moreria, lo qual nos ha respost e scrit que és content e li plau que al dit Hamet Elvallencí sia feta comissió, e que sia scrivà de la dita moreria en loch de aquel revocat, e havent per revocat Çaat Marran, de la dita scrivania, que aquell havia e. regia per aquell en la dita moreria. Per què nós ab la present comanam al dit Hamet Elvalencí la dita scrivania, la qual rebea tots los acidachs e les cartes entre los moros de la dita moreria e del terme de la ciutat de Sogorp, seguons Cuna e Xara de moros. Revocant e havent per revocat al dit Çaat Marren, de la dita scrivania. E noresmenys, 
manam al dit Amet Elvalencí que los achcidachs e cartes que rebrà, que aquelles reba seguons Çuna e Xara de moros, sots pena de sent florins d'or als cóffrens del dit senyor rey applicadors. Manants a vosaltres e a universes e sengles officials e loch de senyoria tinents, que lo dit Amet El Valencí haiats e tingats per scrivà de la dita moreria e del terme de la dita ciutat de Sogorp, e no nengun altre, sots la dita pena de cent florins als cóffrens del dit Senyor Rey applicadors. En testimoni de les quals coses manam ésser feta a vosaltres e al dit Amet Elvalencí la present nostra letra ab lo sagell del nostre offici sagellada.

Dada en València, a vintitrès dies de març, de l'any de la nativitat de Nostre Senyor Mil CCCC trenta hu. Johan Mercader, batle general.

\section{IV}

1445, marzo, 11, Ayódar.

Joban Rois de Castellblanc, señor de Ayódar, escribe al alcadi general Ali de Bellvís (I), pidiéndole que fuera a su lugar para procesar a unos moros delincuentes que tenia presos.

ARV, Batlia, Letres i Privilegis, núm. 1149, carta suelta original junto fol. 446

IHS. IHS.

Al molt honrat Ali de Bellvís, alcadí de la morería de Valencia, directa,

Ali de Bellvís, alcadí, trobares como en dias pasados huvese asegurado hun moro de Eyea, lo qual hera vaçalo mio he ell fuese venido a mi lugar vista mi aseguración; e ell estando en ell lugar han-lo acugelado quatro moros de mi lugar mesmo he otros dos de la Tore Somera. Hesto es estado fego a mano de mi alamin, ell consentiendo en el dicho fego; por que yo tengo presos los digos moros. He a ben dos meses que están presos, per que vos ruego que en todas maneras vos seades aquí hu vuestro figo la sepmana aprés Pasqua en la Tore Fondonera, esto por que deliures los fegos he que sean ben castigados, car con la riquesa que tenen no puedan a senyor nenguno. Por tanto, vos ruego que fagaeis por manera que dones recabdo en los fegos desús digos. He por a la present no vos digo más sino que Dios sea con vos, amen.

Escrita en Ayodar a XI de mars.

Ruego vos que me fagues respuesta

Prest a vuestra honor con el portador de la present.

Johan Rois e de Casteyllblanc. 
1476, septiembre, 4, Valencia.

Mahomat de Bellvis (I), alcadi general, otorga a Ali Amade Aycicot, el oficio de lugarteniente de alcadi en la moreria de la ciudad de Lleida, conservando la jurisdicción sobre las apelaciones.

ARV, Protocolos, Johan de Campos (minor), n. 442, fol. s/n.

Sia a tots manifesta cosa com Mahomat Bellvís, moro habitador de la moreria de València, alcadí e scrivà general de tota la terra e senyoria del molt alt senyor rey, e senyaladament en la ciutat de Leyda, segons que consta del dit son poder per privilegis reyals en la ciutat de Çaragoça e en València, als quals me reffir, ab poder de fer e crear lochtinents e substituhits en les dites moreries reyals, en aquests noms, haüda bona relació de la fe e sufficiència, indústria e bona disposició de tu, Ali Amade Aycicot, moro ferrer de la morería de la dita ciutat de Leyda, e per alguns bons respectes, haüts per revocats qualsevol lochtinents de alcadi per mi en la dita moreria fets sens infamia de aquells, ara de nou faç, cree e constitueixcsch lochtinent meu d'alcadí a vós, dit Ali Amade Aycicot, ferrer, en la dita moreria de Leyda, ab totes aquelles priminències, drets, fruyts e emoluments al dit offici de lochtinent de alcadí pertanyents, dants e atorgants a vós tot aquell poder que per los dits senyors reys de Aragó me són stats donats e atribuiits en la dita moreria, tantum pregants, exortants a tots e sengles officials de la dita ciutat de Leyda que en exercir lo dit offici de lochtinent de alcadí no. us donen destorp e enpaig algú, ans vos donen consell, favor e ajuda si per vós requests ne seran tota hora e quant requests ne seran, dans e concedentes vos la dita locumtenència ab tots los incidents dependents com yo a vos ab los precedents li dona e comana. En testimoni de les quals coses tots e sengles vos faç fer per lo notari deiúscrit la present locumtenència, per haver-ne memoria en sdevenidor.

Fon fet açò en València, a IIII de setembre, any MCCCC.LXXVI. ferm.

Sintyal de mi, Mahomat Bellvís, alcadí del senyor rey, qui aço atorch a

Presents testimonis en Nicholau de Campos, studiant, e Ali, fill de Mahomat Faç, de Nàquera.

1488, agosto,?, Petrés.

Abdulmagip fill de Mabomat Megip, firma carta de "acidach" a su esposa Nusa, por un valor de unos 191 sueldos, entre bienes muebles e inmuebles, que poseía en Petrés, excepto un campo situado en la partida llamada Sebita. 
ARV, Batlia, Pleits, núm. 1438 Tercera mà. Pleits 1515, f. 22 r. v.

En nom de Déu, dóna Abdulmagip, fill de Mahomat, a sa muller Nusa: Un macho vermell que ha clos per vàlua de cent sous.

$\mathrm{Y}$ un asse per lo preu (de) XXX sous.

Hi hun gramallo usat per XX sous.

E un a fer pintar, per $X$ sous.

E una màrfega de lit per quatre sous.

E un devantal penjat, tres sous.

E dos buchs, tres sous.

E dos jeres, cinch sous.

E un trespanti gran per a llit, per VI sous.

E una caldera per VIII sous.

E una paella, per dos sous.

E tot lo que ell té de poch o molt, béns mobles e semovents, y aygues, y mobles, y robes, y terres regadius y seguans, conreats e sense conrear, hi cassa, entre or y perles, en lo dit loch de Petrés e fora de aquella. He se aturat lo dit nomenat, poch ni molt, sinó que $\mathrm{u}$ donarà la dita sa muller Nusa e tot allò en compte del seu adsidach, farem en lo seu matremoni a la dita sa muller de totes les altres coses. Salvo lo camp que lo dit té en la partida de Sebita, que allò ce ha aturat per a ell.

La dita donació, sense neguna manera de pacte nengú, sinó pura sa bona voluntat, la qual es deu vui per amor de Déu, censse nenguna cautella, hi aquell salvada la quantitat de tot allò. Lo qual ab allò espera allargar de nostre senyor Déu, que Déu als que fan be los alberga en lo altre món.

Y dita Nuza, à rebuda donadiu de tot lo qu'és nomenat, hi lli a pres y com a béns de la herència he $\mathrm{u}$ farà poder d'ella, segons se acostuma, segons Suna e Xara en los dits donatius. Y possat a ella y en poder d'ella, com a béns d'ella, segons Suna e Xara.

Tertificaren sobre ells en tot allò, los quals al seu testimoni sobre ells e sobre ses persones e hohit allò de ells, y conèxer adaquells, e aquells en sa sanitat fahedora.

E açò en kalendari del principi de agost any D.CCC.LXVI, conte morisch. Testimonis Ali Alcarahuy e Azmet fill Saat Fatden.

Autentiçat e fermat per mans de lo scrivent de Déu Abdulmegip, fill de Alí, fill de Alí, fill de Azmet Adris.

\section{VII}

1488, diciembre, ?, Petrés.

Ali fill de Abrabim Bintnacer, otorga carta de seguridad a su mujer Nuza, de que no movería pleitos ni demandas contra los bienes que poseía su esposa, sobre los cuales reconocia no tener ningún derecho. 
ARV, Batlia, Pleits, núm. 1438, Tercera mà de 1515, ff. 21 r. 22 v.

En nom de Déu, testifica Alii, fill de Abrahim Bintnacer, sobre sa persona als testimonis de aquell acte en sa sanitat fahedora en parlar a la veritat atorgat en allò que moure ninguna demanda, ninguna justícia, ningun dret en tot lo que és en poder e mans de sa muller Nuza, de cassa e rexats, regadiu e cequà, conreats e sense conrear, robes, moble, joyes, perles y or, bèsties e altres coses de poch o molt. E que tot allò com béns de la dita sa muller Nusa, e que ell ne té ningun dret en tot allò, ni demanda, ni dret nengú, ni poch ni molt, e per qualsevulla hora que lo dit Alí se levarà contra la dita sa muller Nuza, en lo damunt nomenat e altres coses, que lo dit seu demanar e lo qui demanarà en loch d'ell serà nulle hi falç, e ses rahons nulles hi ses proves que no tinguen loch nengú per qualsevulla via.

Testificarà sobre lo dit Alii, en la qual ha testificat sobre si mateix en lo damunt dit, a renuncia a tot son dret e a tota sa demanda.

En allò testificaran, ço es testimonis en kalendari en la dareria del mes de dehembre any D.CCC.LXVI., conte morisch.

Testimonis Azmet, fill de Çat Donhi, Abdalla fill Mohomat Alpirson.

Autentiçat e fermat per mans del scrivent cervent de Déu Abdulmegipl, fill de Alik, fill de Azmet Adriç, que Déu sia ab tots.

\section{RÉSUMÉ}

Les mudejars valenciens qui firent partie de l'ancien règne de Valencia pendant le bas Moyen Âge, conservèrent, parmi d'autres institutions correspondant à la période islamique, les tribunaux musulmans héritiers des cadis précédents, qui se chargèrent d'appliquer les normes islamiques dans les procès ou les plaignants étaient uniquement musulmans.

La Cour des cadis prenaient conseil des Ulémas (docteurs de la loi) ou de juristes expérimentés en législation islamique de même que des autres juridictions.

Il y eut des collaborateurs de justice, tels les procurcurs dans les procès et, aussi, des auxiliaires de justice comme les greffiers, les traducteurs, les anciens magistrats d'Aragon et les policiers, chargés, par le Conseil des cadis, de faciliter le déroulement de leurs fonctions. On aida aussi les juridictions de bourreaux et de geôliers, la plus part du temps très semblables à l'organisation judiciaire des privilèges valenciens.

De toute cette organisation des tribunaux des juridictions musulmanes de Valencia, on peut remarquer que la caractéristique principale a été de préserver les aspects de base de la justice islamique tout en introduisant progressivement de notables influences issues de la justice valencienne et de ses privilèges. 


\section{SUMMARY}

Muslims from Valencia who leaved in the old reign of Valencia during the early Middle Ages, conserved, among other institutions corresponding to the islamic period, the tribunals of the Cadi institutions, inheritor of the preceding Cadis, who looked after the application of the islamic norms in the cases where all the litigators were muslims.

The court of Cadis was advised by "alfaquíes» or expert jurists in islamic legislatión, as well as by other Cadis.

The staff was composed by justice collaborators, attorneys, judicial auxiliaries such as court clerks, translators, "zalmedines" and police officers; supposed to help it working. The Cadis also had hangmen and jailers, usually the same as the Valencian "foral» judicial organisation.

The main characteristic of the all organisation of the Valencian Moorish Cadi tribunals was the preservation of the basic aspects of the islamic justice, introducing though progressively important influences of the Valencian justice. 